\title{
JANENGAN SEBAGAI SENI TRADISIONAL ISLAM-JAWA
}

\author{
Akhmad Arif Junaidi, dkk. \\ IAIN Walisongo Semarang \\ e-mail: arif_unaidi2003@yahoo.com
}

\begin{abstract}
This paper is based on the cultural reality of Javanese Muslim society especially in Islamic Javanese traditional music. The cultural expression of Islamic-Javanese music is very diverse and reflecting the diversity of the "face" of Islam that has been adapted to the local culture. Janengan's Islamic Javanese traditional music is an expression from three different cultural music traditions: Javanese music tradition, Middle Eastern music traditions (Arabic), and currently has been developed with a combination of Western music such as pop. The combination of three different musical traditions creates a unique creativity in Javanese music character. The character also encourages the values covering musical values, cultural values, and religious values. Thematically, the Janengan's lyrics contain a variety of Islamic teaching such as monotheism, shari'ah and sufism.

$* * *$

Tulisan ini dilatarbelakangi satu realitas budaya yang dihasilkan dari kehidupan masyarakat Muslim Jawa khususnya seni musik tradisional Islam-Jawa. Ekspresi kebudayaan Islam-Jawa dalam seni musik ini sangat beragam dan mencerminkan keberagaman "wajah" Islam yang telah beradaptasi dengan budaya lokal. Musik tradisional Islam-Jawa Janengan merupakan perwujudan dari perpaduan tiga unsur tradisi musik, yakni tradisi musik Jawa, tradisi musik Islam Timur Tengah (Arab) dan kini telah dikembangkan dengan kombinasi musik Barat seperti pop. Perpaduan ketiga unsur tradisi musik yang berbeda ini membentuk suatu hasil kreativitas yang unik bercirikan musik Jawa. Musik tradisional Islam-Jawa ini juga melahirkan nilai-nilai yang meliputi nilai-nilai musikal, nilai-nilai kultural, dan nilai-nilai religius. Secara tematik syair-syair Janengan berisi berbagai ajaran seperti akidah (tauhid), syari'at dan tasawuf.
\end{abstract}

Keywords: Janengan, budaya lokal, tradisi Islam-Jawa 


\section{A. Pendahuluan}

Islam sebagai sebuah tradisi yang berinteraksi dengan tradisi lain seringkali menciptakan tradisi baru. Sebuah tradisi hasil hibridasi antara Islam di satu sisi dan tradisi lokal pada sisi yang lain. Pada masyarakat Jawa hasil hibridasi ini kemudian dikenal dengan Islam-Jawa yang merupakan bentukan dari akulturasi dengan kebudayaan lokal. Kenyataan ini semakin memperkokoh pandangan bahwa Islam tidaklah hanya berupa sekumpulan doktrin. Melainkan juga, Islam dihayati dan diamalkan oleh para pemeluknya menjadi sebuah realitas kebudayaan. Dengan begitu, akulturasi budaya antara Islam dan kebudayaan lokal adalah bagian dari sekian banyak ekspresi Islam sebagai pandangan hidup dan sumber inspirasi bagi tindakan para pemeluknya.

Salah satu realitas budaya yang dihasilkan dari kehidupan masyarakat Muslim Jawa adalah seni musik tradisional Jawa-Islam. Ekspresi kebudayaan Islam-Jawa dalam seni musik ini sangat beragam, dan mencerminkan keberagaman "wajah" Islam yang telah beradaptasi dengan budaya lokal. Sebut saja misalnya rebana, hadrah, gambus, qasidah, gambang shalawatan, kentrung, santiswaran, gending banyumasan, Janengan, rengkong, rampak religi, rodad, dan nasid. Bahkan jenis-jenis musik tersebut saling berkolaborasi untuk menciptakan harmoni musik yang khas. Kekhasan kebudayaan ini merupakan fakta yang tidak terbantahkan dalam perkembangan Islam di Jawa, bahwa berbagai bentuk seni budaya Islam yang berkembang di Jawa tidak terdapat di Arab.

Berbagai ragam seni musik tradisional Jawa-Islam ini juga menggunakan beragam jenis alat musik, baik yang berupa alat musik perkusi/pukul (misalnya gamelan, kendang, kecapi, arumba, talempong, sampek, kulintang, dan sasando), alat musik gesek (misalnya gitar, biola, rebab dan ohyan), dan alat musik tiup (misalnya suling, terompet, dan sexophone). Dalam penjabarannya, biasanya jenis musik tradional Jawa-Islam mengambil sumber-sumber dari ajaran Islam sebagai spirit moral tetapi kemudian dikemas dengan tradisi Jawa, misalnya bahasa dan syair-syair Jawa. Tetapi banyak juga yang bahasanya tetap menggunakan bahasa Arab, hanya saja musiknya dimainkan dengan musik Jawa. Ketika mereka menyalinnya dengan bahasa Jawa, biasanya mereka adalah orang-orang yang disebut sebagai "Jawa deles" 
(sejati), yang karenanya mereka memakai bahasa Jawa dalam shalawatan dan musik-musik tradisionalnya. Bagi mereka, dengan Bahasa Jawa akan merasa lebih bisa mengartikulasikan gerak batin mereka atas pesan-pesan moral Islam.

Memang tradisi Islam di Jawa banyak yang memakai bahasa Jawa sebagai media komunikasi. Bahasa Jawa yang digunakan cenderung sederhana dan merefleksikan pemahaman tentang agama yang tidak kelewat muskil, tetapi justru menjelma menjadi penghayatan yang personal. Bahkan, pemakaian seni musik tradisional Jawa-Islam ini digunakan sebagai media dakwah Islam sejak Sunan Bonang, dan kemudian dilanjutkan oleh Sunan Kalijaga. Dengan menggunakan media musik tradisional Jawa-Islam, justru dakwah dan syiar agama bisa sampai ke publik lewat kesenian rakyat yang komunikatif semacam ini. Bentuk seni musik hasil dari adaptasi Islam dan kebudayaan Jawa juga terekspresi melalui seni Santiswaran (lagu pujipujian), yang merupakan paduan antara hadrah dan karawitan Jawa sehingga menghasilkan musik yang indah.

Perjalanan dan perkembangan seni musik tradisional Jawa-Islam di Nusantara pada umumnya dan Jawa pada khususnya telah berlangsung cukup lama, yakni sejak masuknya Islam ke Nusantara yang nota bene-nya disebarkan secara damai melalui banyak media, salah satunya adalah media seni dan kebudayaan. Dalam historiografi Islam Nusantara telah umum diketahui bahwa selain berdagang dan menyebarkan agama Islam, para pedagang Arab juga memperkenalkan musik mereka. Alat musik mereka berupa gambus dan rebana. Dari proses itulah muncul orkes-orkes gambus di Nusantara (Indonesia) hingga saat ini. Sementara para penyebar Islam di Jawa (Walisongo) juga melakukan hal serupa, yakni mengelaborasi seni tradisional yang dimiliki oleh masyarakat Jawa dan kemudian dipoles dengan sentuhan-sentuhan nilai Islam. Sunan Bonang dan Sunan Kalijaga adalah beberapa Walisongo yang melakukan cara-cara semacam ini.

Masuknya kolonialisme juga turut mempengaruhi ragam seni musik tradisional ini. Masuknya bangsa Barat ke Indonesia juga membawa pengaruh besar dalam perkembangan musik Indonesia. Para pendatang ini memperkenalkan berbagai alat musik dari negeri mereka, misalnya biola, selo (cello), gitar, seruling (flute), dan ukulele. Berbagai alat musik ini di 
kemudian hari juga digunakan sebagai pemadu kekhasan suara. Perkembangan musik tradisional ini kemudian seperti semakin padu, yakni perpaduan berbagai jenis alat musik (baik tradisional maupun modern) ke dalam satu bentuk jenis musik tersendiri yang khas. Munculnya jenis musik rampak etnoreligi dan gamelan gambang shalawat adalah salah satu perpaduan antara seni musik tradisional dengan seni musik modern.

Tradisi seni budaya Islami tampaknya terus berkembang di Jawa sekalipun mengalami transformasi. Bentuk ritual seni musik tradisional berubah mengikuti aspirasi zaman. Sebagian jadi kontemporer, bahkan ngepop, tetapi napas religi tetap kental dipertahankan. Kelompok Wireng Santi Guna dari Baluwarti Solo, misalnya, menyajikan santiswaran yang sebagian repertoarnya mengacu pada tradisi keraton. Namun, mereka juga menggubah repertoar baru yang bertema kerukunan beragama; mengingatkan tentang pluralitas yang hidup masyarakat. Kelompok ini sejatinya merupakan "pembauran", karena anggotanya - separuhnya ibu-ibu - terdiri dari beragam pemeluk agama; ada Islam, Katolik, Kristen, Hindu, dan Budhis.

Musik tradisional hampir bisa dijumpai di berbagai daerah di seluruh Indonesia dengan berbagai keunikan dan kekhasan masing-masing. Keunikan dan kekhasan tersebut bisa dilihat dari lagu, bentuk/organologi instrumen musiknya, teknik permainannya, maupun penyajiannya. Instrumen musik perkusi misalnya. Jenis musik ini adalah menggunakan instrumen musik yang teknik permainannya di pukul, baik menggunakan tangan maupun stik. Beberapa alat musik dalam kategori ini adalah gamelan, arumba, kendang, kolintang, tifa, talempong, rebana, bedug, jimbe dan lain sebagainya. Di daerah Jawa alat musik perkusi yang populer adalah gamelan dan kendang.

Beragamnya ekspresi musik tradisional Jawa-Islam merupakan kekayaan budaya yang merupakan kekuatan sejarah. Tetapi apa yang dimaksud dengan budaya tergantung dari world view si pendefinisi. Tentunya ini akan melahirkan sikap dan persepsi yang terfokus pada sederatan fenomena dan melupakan fenomena yang lain. Padahal dalam ranah budaya, banyak gejala dan praktik budaya yang tidak tersorot oleh mainstream keilmuan. Dalam kehidupan empirik, banyak sekali budaya-budaya lokal yang mempunyai label atau identitas keagamaan yang sangat beraneka ragam di berbagai daerah di seluruh Indonesia, apalagi Jawa. Kebudayaan tersebut lahir di 
dalam masyarakat melalui proses human culture interaction yang hanya bisa dipacu oleh culture events.

Dalam perjalanannya, beragam ekspresi kesenian tradisional Jawa-Islam ini banyak digunakan untuk berbagai keperluan. Misalnya sebagai sarana hiburan, sarana ekspresi diri, sarana komunikasi, sarana ekonomi, dan tentu saja sebagai sarana dakwah. Bahkan, pada perkembangan kontemporer saat ini banyak masyarakat yang mulai melirik musik tradisional sebagai musik alternatif. Salah satu faktor yang menyebabkan diterimanya musik tradisional ini adalah kenyataan bahwa masyarakat tengah mengalami krisis pijakan tradisi di tengah perubahan modernisasi yang begitu deras. Perubahan (transformasi) sosial dan budaya yang berlangsung sangat cepat telah meruntuhkan sendi-sendi kehidupan masyarakat. Perubahan ini telah mengakibatkan masyarakat hidup dalam situasi anomi yang ditandai dengan hancurnya sistem nilai lama dan belum terbangunnya sistem nilai baru sebagai alternatif. Akibatnya masyarakat pun dihadapkan pada situasi sulit antara meninggalkan nilai-nilai lama dan sepenuhnya merengkuh modernitas atau sebaliknya menolak sepenunya modernitas sambil berpegang pada tradisi yang mereka miliki. Dalam konteks semacam inilah, maka berkembangnya musik tradisional dengan sentuhan industri musik modern seolah menjadi outlet bagi masyarakat. Keberadaan musik tradisional JawaIslam menjadi semacam jeda yang menjadi ruang psikologis di tengah kerasnya pergulatan hidup sehari-hari. Keindahan lagu dan pesan yang ada di dalamnya menjadi oase bagi masyarakat Muslim di tengah gempuran perubahan dan modernitas yang terasa gersang.

Salah satu jenis musik, tradisonal itu adalah Janengan yang eksis di tengah masyarakat Kebumen. Janengan merupakan tradisi seni Jawa-Islam yang menjadi outlet kehidupan masyarakat sekitar dari rutinitas sehari-hari. Janengan biasa dilakukan pada malam Jum'at dari mulai habis Isya hingga tengah malam. Akan tetapi, ketika keberadaan musik tradisional ini tidak dikemas dengan suasana masyarakat yang kosmopolit, maka bukan tidak mungkin perkembangan musik tradisional memiiki hambatan. Kekhawatiran ini bisa saja menjadi kenyataan ketika perhatian dari lembaga-lembaga yang memiliki peran sebagai stakeholders tidak memiliki perhatian serius terhadap perkembangan seni musik tradisional Jawa-Islam ini. 
Upaya-upaya konservasi terhadap seni musik tradisional ini adalah bagian dari langkah panjang menjaga dan sekaligus mengembangkan seni musik yang khas ini. Dengan latar belakang di atas maka lembaga penelitian IAIN Walisongo Semarang memandang perlu dilakukan penelitian konservasi terhadap seni musik tradisional Jawa-Islam dalam kehidupan masyarakat Islam-Jawa. Penelitian ini tentu saja selain menginventarisir berbagai jenis, ragam, dan corak seni musik tradisional ini juga sekaligus melakukan konservasi dan pengembangan, agar peran seni musik tradisional yang memiliki peran setrategis ini tetap menjadi bagian dari kekayaan dan kekuatan sejarah peradaban Islam di Nusantara, khususnya Jawa.

Fokus dari riset ini adalah seni musik tradisional Jawa-Islam yang ada di Kebumen Jawa Tengah yaitu seni Janengan. Penelitian ini berusaha untuk mengungkap sejarah, eksistensi dan fungsi Janengan di tengah masyarakat pemiliknya. Sebagai tradisi yang mengakar di masyarakat maka bisa diduga bahwa seni tradisional Janengan ini memiliki akar dalam sejarah perkembangan kehidupan masyarakat, khususnya Islam Kebumen. Sebab itu rumusan masalah riset ini adalah mengenai unsur-unsur yang ada pada seni Janengan, isi kandungan ajaran Islam yang terdapat dalam lagu-lagu Janengan, fungsi Janengan bagi masyarakat Kebumen, dan bagaimana langkah-langkah konservasi yang bisa dilakukan bagi kelestarian seni tersebut.

\section{B. Musik Tradisional Islam-Jawa}

Beberapa penelitian telah melakukan pembahasan mengenai ragam seni musik tradisional Jawa-Islam. Penelitian itu pernah dilakukan oleh: pertama, Muh. Syafrudin, dkk., dengan judul "Sinkritisme Budaya Jawa-Islam (Sejarah dan Peranan Seni Jemblung Katong Wecana dalam Penyebaran Agama Islam di Kabupaten Ponorogo)." Hasil penelitian Muh. Syarifudin, dkk., ini menunjukkan bahwa seni Jemblung Katong Wecana merupakan kesenian asli ciptaan Raden Katong sebagai upaya membaurkan seni jemblung dengan ajaran Islam sebagai media penyebaran Islam ke tengah-tengah masyarakat Ponorogo yang memiliki agama, kepercayaan, dan budaya lokal yang telah lama mapan. Tampaknya dalam proses dialogis antar keduanya, budaya Jawa lebih mewarnai dibanding ajaran Islam dalam seni Jemblung Katong Wacana. 
Salah satu dampaknya karena proses akulturasi dan inkulturasi budaya, menyebabkan terbentuknya budaya "sinkretik" di kalangan masyarakat Muslim Ponorogo.

Kedua, Yusnita Ade, dkk., yang berjudul "Rudat Mutiara Budaya yang Tersembunyi". Rudat adalah kesenian tradisional khas Jawa Barat (Tasikmalaya, Banten dan lainnya) yang merupakan perpaduan unsur tari, syair shalawat, dan olah kanuragan yang berpadu dengan tabuhan terbang dan tepuk tangan. Rudat terdiri dari sejumlah musik perkusi yang dimainkan oleh setidaknya delapan orang "penerbang" (pemain musik terbang/rebana) yang mengiringi tujuh hingga dua belas penari. Menurut beberapa tokoh rudat, nama "rudat" diambil dari nama alat yang dimainkan dalam kesenian ini. Alat musik tersebut berbentuk bundar yang dimainkan dengan cara dipukul.

Ketiga, Mambaul Ngadimah yang berjudul "Kelestarian Shalawat Gembrungan (Integrasi Ajaran Islam dengan Seni Budaya Lokal: Studi Kasus di Desa Gotak Klorogan Kecamatan Geger Kabupaten Madiun)." Penelitian Mambaul ini menunjukkan bahwa faktor-faktor yang mempengaruhi seni musik gembrung bisa bertahan adalah karena adanya motivasi religius dan ekonomi bagi subjek pemain gembrung, estetika, ekspresi identitas seni Islam, penyempurnaan naskah, dan figur pimpinan paguyuban gembrung yang kharismatik. Selain itu juga seni musik gembrung merupakan kesenian tradisional Islam yang murah dan merakyat, motivasi religius bagi penanggap dan audience, romantisme historis dengan melestarikan budaya leluhur, kemudahan perizinan dan penyelenggaraan festival dari institusi pendidikan dan instansi pemerintah terkait. Sementara faktor penghambat kelestarian seni musik gembrung adalah kurangnya profesionalisme sumber daya manusia (SDM) yang ada, naskah syair shalawat gembrung yang klasik sehingga bahasanya sulit dipahami audience karena masih menggunakan bahasa Jawa zaman kerajaan Mataram, dan musik gembrung terkesan monoton dan kuno. Selain itu juga disebabkan karena tidak ada dukungan dari aparat pemerintah terkait untuk melestarikan seni musik gembrung, dan apresiasi masyarakat semakin berkurang karena banyaknya pilihan untuk menikmati hiburan dari berbagai jenis musik modern.

Jika dicermati, penelitian di atas membahas perpaduan budaya lokal dan Islam dan keduanya dilakukan di daerah berbeda. Penelitian yang akan di- 
lakukan saat ini jelas berbeda dengan kedua penelitian di atas. Penelitian ini akan difokuskan mengenai bagaimana ragam, bentuk, dan jenis-jenis seni musik tradisional Jawa-Islam, terutama di Jawa Tengah terkait dengan keberadaan, dan apa faktor mendukung dan menghambatnya serta bagaimana sistem pewarisannya. Dengan begitu, diharapkan penelitian ini sesuai dengan tujuan dan manfaat penelitian sebagaimana telah dijelakan sebelumnya, yakni menemukan langkah-langkah konservasi yang mungkin bisa dilakukan guna mempertahankan kelestarian seni musik tradisional Jawa-Islam di Jawa Tengah.

Kuntowijoyo (1998) mengemukakan bahwa kesenian yang merupakan ekspresi dari keislaman itu setidaknya memiliki tiga karakteristik: (1) dapat berfungsi sebagai ibadah, tazkiyah, dan tasbih, (2) dapat menjadi identitas kelompok, dan (3) dapat berfungsi sebagai syiar. Shalawat secara khusus merujuk pada berkah yang dimohonkan kaum Muslimin atas Nabi Muhammad SAW. Sebagaimana firman Allah:

"Sesungguhnya Allah dan malaikat-malaikatnya bershalawat untuk nabi. Hai orang-orang yang beriman, bershalawatlah kalian untuk nabi dan ucapkanlah salam penghormatan."1

Seni musik tradisional Jawa-Islam sesungguhnya telah memiliki ketiga karakteristik tersebut. Seni musik jenis ini jelas mengandung 'ibadah dan tasbih serta syiar, karena di dalamnya berisikan ajaran Islam. dan syair-syair yang sarat dengan tasbih terhadap Allah SWT. Dengan begitu, maka dengan sendirinya, seni musik tradisional Jawa-Islam telah memberikan identitas atas kehidupan kaum Muslimin, yang dapat dilihat dan dirasakan oleh orang lain. Strategi adaptasi dalam suatu masyarakat tercermin pada peta kognitif mereka yang dipelajarinya melalui proses sosialisasi. Berbagai pengalaman mereka dikategorisasikan dalam sebuah peta kognitif kebudayaan sehingga memungkinkan seseorang atau organisai tetap survival. Menurut Talcott Parsons-dalam karya belakangannya-ada empat fungsi penting untuk semua sistem "tindakan", terkenal dengan skema AGIL.2 Suatu fungsi (function) adalah kumpulan kegiatan yang ditunjukkan ke arah pemenuhan

${ }^{1}$ QS. al-Ahzab [33]: 56.

${ }^{2}$ Ritzer \& Goodman, Teori Sosiologi Modern, (Jakarta: Prenada Media, 2004). 
kebutuhan tertentu atau kebutuhan sistem. Dengan menggunakan definisi ini, Parsons yakin bahwa ada empat fungsi penting diperlukan semua sistem yakni adaptation (A), goal attainment (G), integration (I), dan latensi (L). Agar tetap bertahan (survive), suatu sistem harus mempunyai empat fungsi ini:

1. Adaptation (Adaptasi); sebuah sistem harus menanggulangi situasi eksternal yang gawat. Sistem harus menyesuaikan diri dengan lingkungan dan menyesuaikan lingkungan itu dengan kebutuhannya.

2. Goal Attainment (Pencapaian Tujuan); sebuah sistem harus mendefinisikan dan mencapai tujuan utamanya.

3. Integration (Integrasi); sebuah sistem harus mengatur antar hubungan bagian-bagian yang menjadi komponennya. Sistem juga harus mengelola antar hubungan ketiga fungsi penting lainnya.

4. Latency (Latensi atau pemeliharaan pola); sebuah sistem harus melengkapi, memelihara dan memperbaiki, baik motivasi individual maupun pola-pola kultural yang menciptakan dan menopang motivasi.

Teori fungsionalisme struktural Talcott Parsons, kiranya dapat dipakai sebagai kerangka konseptual yang diharapkan mampu menjelaskan kelestarian seni musik tradisional Jawa-Islam. Dengan anggapan, bahwa kelestarian seni musik jenis ini pada dasarnya terintegrasi atas dasar komitmen anggotanya akan nilai-nilai ajaran Islam, melalui proses penyesuaian dan institusionalisasi dengan seni-budaya lokal Jawa dalam rangka memenuhi tuntutan kebutuhan syiar Islam melalui seni vokal dan musik untuk menghadapi situasi dan kondisi eksternal, agar mampu melangsungkan kehidupan paguyuban atau organisasinya (survive) dan memungkinkan dapat mengantisipasi peristiwa-peristiwa yang akan datang.

\section{Janengan: Musik Islam-Jawa}

\section{Asal-usul Janengan}

Janengan merupakan salah satu seni tradisi yang tumbuh dan berkembang di Kebumen. Sebagian masyarakat Kebumen menyebutnya dengan shalawat Jamjaneng, sebagian yang lain menyebutnya dengan Janengan. Meskipun dari segi unsur pembentuknya seni ini mirip dengan seni tradisi lain seperti srakal dan jembrung yang berkembang luas di Jawa Timur dan 
Jawa Tengah masyarakat Kebumen menyebut seni tradisi ini sebagai khas musik tradisional Kebumen. Hal ini karena seni Janengan tidak berkembang di wilayah lain di sekitar Kebumen seperti Purworejo, Wonosobo, Banjarnegara dan Purbalingga. Sebaliknya hampir di seluruh desa di Kebumen terdapat kelompok Janengan ini. Diperkirakan tidak kurang dari 416 kelompok musikJanengan di Kebumen.

Para pemilik tradisi Janengan menuturkan bahwa Janengan merupakan warisan tradisi Islam yang diwariskan oleh nenek moyang mereka sejak masa awal perkembangan Islam. Mereka melihat Janengan sebagai seni khas Islam Kebumen yang sudah barang tentu berbeda dengan seni tradisi lain yang seperti dolalak di Purworejo. Sulit dilacak mulai kapan seni Janengan di Kebumen mulai ada. Para pemilik kelompok dan pemain Janengan tampaknya bersepakat bahwa Janengan berasal dari kata "Zamjani", nama tokoh yang dipercaya sebagai pencipta musik tradisional Islam-Jawa ini. Tradisi masyarakat setempat mempercayai Syekh Zamjani merupakan tokoh yang memadukan syair-syair yang diciptakan oleh Sunan Kalijaga dan musik Jawa ciptaan Ibrahim al-Samarqandi (Brahim Samarkandi). Tokoh ini diperkirakan hidup pada abad ke-15-16, masa dimana Islam berkembang pesat di Tanah Jawa. Menurut penuturan tokoh setempat Syekh Zamjani berasal dari Kutawinangun, yaitu tempat asal pendiri Kebumen yang bernama Joko Sangrib. Paduan Syair dan musik Jawa oleh Syekh Zamjani itulah yang kemudian dikenal oleh masyarakat sebagai Janengan.

Seni tradisi Janengan sebagaimana seni tradisi lainnya tentu menghadapi tantangan zaman yang sangat berat. Pada awalnya seiring dengan perkembangan Islam di Jawa Janengan berkembang seiring dengan pertumbuhan dan perkembangan Islam-Jawa yang menghasilkan berbagi varian tradisi Islam.

\section{Bentuk Lagu Janengan}

Seni tradisi Janengan memadukan musik Jawa dan syi'iran (singiran). Dalam Janengan lagu syi'iran terdiri dari shalawat dan syi'ir Jawa. Namun juga terdapat lagu-lagu Janengan yang hanya terdiri dari bait-bait lagu syi'ir Jawa. Salah satu teknik menyanyikan lagu-lagu dalam Janengan adalah penyanyi melagukannya dengan suara melengking dan dengan nada yang sangat tinggi. Kemampuan bernyanyi semacam ini jarang dimiliki, para pegiat 
seni Janengan. Oleh karena itu pemimpin Kelompok Janengan yang ada sekarang kebanyakan telah merubah teknik semacam ini dan menggantinya dengan nada yang lebih rendah dan tidak melengking. Karena alasan ini pula biasanya pimpinan Janengan yang biasanya disebut dengan dalang merupakan orang yang memiliki kemampuan dan kualitas suara melengking. Dalang merupakan pemimpin kelompok Janengan yeng bertugas mengatur irama Janengan dari mulai pembukaan sampai penutup.

Menurut salah satu sesepuh kelompok Janengan "Margo Eling", untuk mendapatkan suara semacam itu seseorang harus melakukan gurah sekaligus laku untuk menghindari makanan tertentu seperti trancam terong, dan makanan lainnya yang akan berpengaruh terhadap kualitas suara seseorang. Kualitas suara tinggi dan kemampuan untuk melantunkan lagu dalam waktu yang sangat lama tentu sangat dibutuhkan, mengingat Janengan biasa berlangsung sampai tengah malam, bahkan seringkali semalam suntuk. Salah seorang pegiat Janengan menuturkan dalam acara Janengan rutin biasanya berlangsung dari mulai jam 20.00 WIB sampai jam 12.00 WIB. Acara semacam ini pula yang berlangsung di salah satu Stasiun Radio Kebumen (IN FM). Di stasiun tersebut acara Janengan dilakukan setiap malam Jum'at yang berlangsung dari jam 20.00 WIB sampai jam 12.00 WIB. Secara bergiliran kelompok-kelompok Janengan yang berasal dari berbagai desa di Kebumen diundang untuk bermain Janengan. Tentu saja Janengan yang dimainkan di radio tersebut sangat variatif baik dari segi lagu yang dinyangikan maupun alat musik yang digunakan. Tidak jarang Janengan telah dicampur dengan campursari dengan kombinasi alat musik Janengan asli dan alat musik modern. Di stasiun radio IN FM kini tersimpan dukentasi yang cukup rapi acara live berbagai kelompokJanengan.

Pada zaman dahulu dalam Janengan juga diisi cerita Babad Menak (Umar Maya Umar Madi). Penceritaan tokoh ini dalam Janengan tentu sangat terkait erat dengan kepentingan dakwah. Alkisah pada masa para Khalifah memerintah dan menyebarkan agama Islam di tanah Arab, tersebutlah seorang pahlawan Arab yang gagah berani dan tangguh dari berbagai macam senjata perang, bernama Umar Maya. Ia memiliki kesaktian sehingga terkenal ke seluruh penjuru Negara-negara yang sudah memeluk agama Islam. Negara-negara yang belum memeluk agama Islam pun merasa gentar akan kesaktian pahlawan Islam tersebut. 
Adapun rahasia kesaktian Umar Maya itu terletak pada endong (kantung yang terbuat dari kain). Oleh karena endong tersebut tidak pernah lepas dari badannya. Kemana saja ia pergi, endong tersebut selalu melekat pada badannya, mandi sekalipun. Berkat kesaktian dan khasiat endong-nya ini, kerajaan Arab semakin lama makin luas saja. Akibatnya, makin banyaklah Negara yang mengabdi kepada Negara Arab, yang mengakibatkan upeti datang melimpah ruah setiap tahun. Maka dengan demikian, kerajaan Arab pun makin makmur dan kaya raya.

Diceritakan ada sebuah kerajaan yang belum takluk, kerajaan itu sudah lama menunggu kesempatan untuk menyerang kerajaan Arab karena telah mengetahui rahasia Umar Maya, yaitu terletak pada kantungnya. Untuk mengalahkan Negara Arab, satu-satunya cara hanya dengan mencuri endong Umar Maya. Berkat kecerdikan mata-mata yang dikirim ke Negara Arab, raja itu berhasil mencuri kantung Umar Maya. Alangkah gegernya kerajaan dari rakyat Arab. Ketika tersiar kabar bahwa kantung azimat hilang. Lamakelamaan terciumlah berita bahwa pencurinya itu adalah dari kerajaan Wajesi.

Kerajaan Arab dengan bantuan kerajaan-kerajaan (negara-negara) yang telah takluk dan sekarang telah menjadi sahabat, menyerang kerajaan Wajesi. Peperangan ini sangat dahsyat karena betapa gigihnya perlawanan balatentara Arab, tetapi karena musuh mempunyai endong Umar Maya, musuh sukar dikalahkan. Umar Maya yang mati-matian berjuang untuk mendapatkan kembali endong wasiatnya, beberapa kali terancam jiwanya. Akan tetapi karena keberanian bala tentara Islam yang pantang mundur dan dibekali keimanan kepada Allah, akhirnya Raja Wajesi menyatakan takluk dan dengan demikian raja dan rakyatnya masuk Islam. Umar Maya dapat memiliki kembali endong wasiatnya, yang pernah jatuh ke tangan musuh.

\section{Alat Musik}

Pada awalnya Jenengan merupakan seni tradisi Islam yang sangat sederhana. Hal ini bisa dilihat dari alat musik yang digunakan. Musik tradisional Janengan pada awalnya hanya terdiri dari alat musik tepuk. Sebelum mengalami modifikasi seperti yang dilakukan oleh berbagai kelompok Janengan dewasa ini, alat musik Janengan terdiri dari tuling, kemeng, ukel, gong dan kendang. Semuanya merupakan jenis alat musik 
ritmis dengan teknik bermain dipukul dengan tangan atau kayu. Tuleng alat musik Janengan terbuat dari bambu. Teknik membunyikan alat ini adalah dengan dipukul menggunakan kayu pemukul. Alat tuleng yang asli adalah sejenis kendang yang sangat kecil dengan teknik membunyikan dipukul dengan jari-jari tangan seperti membunyikan terbang. Kemeng, ukel dan gong adalah alat musik yang biasanya sering disebut dengan terbang Jawa. Adapun yang membedakan adalah ukuran ketiganya. Kemeng adalah terbang Jawa dengan ukur yang kecil, Ukel adalah terbang Jawa dengan ukuran sedang dan gong adalah terbang Jawa dengan ukuran besar. Adapun kendang dalam Janengan adalah sejenis dengan kendang Jawa yang biasa digunakan dalam gamelan mupun kendang jaipong. Namun pada awalnya kendang janeng hanya menggunakan satu kendang yaitu kendang gamelan ataupun jaipong yang memiliki ukuran paling besar.

Dalam perkembangannya bertambah menjadi alat musik tepuk dan pukul. Sekarang sebagian kelompok seni Janengan juga menggunakan alat musik elektronik seperti keyboard. Alat musik tepuk terdiri dari kendang, ukel (terbang kecil 1, sedang 1 dan besar). jidor (1 buah). Sedangkan untuk alat musik pukul menggunakan angklung pukul). Dengan perkembangan tuntutan agar Janengan bisa diterima oleh generai muda, maka kini sebagian kelompok msuik Janengan juga menggunakan alat-alat musik yang lain seperti gitar dan keyboard.

\section{Kandungan Lagu Janengan}

Syair lagu Janengan berupa shalawat yang dikomibinasi dengan syair atau yang biasa dikenal dengan singir. Oleh karenanya sebagian masyarakat menyebutnya dengan shalawat Janengan. Dari sudut material naskah lagulagu Janengan sebagaimana naskah-naskah syi'iran yang tersebar pada masyarakat Jawa pada awalnya ditulis dalam huruf Arab pegon. Akan tetapi perkembangan baru masyarakat lebih familiar dengan huruf Latin ketimbang huruf pegon, maka naskah-naskah tersebut ditransliterasi dengan hurufhuruf Latin. Bahkan dari segi pengucapan syair shalawat itu diucapkan dengan dialek khas Kebumen. Hal ini bisa dilihat pada kutipan naskah sebagai berikut: 


\section{Assalamu Ngalaik \\ Assalamu Ngalaik \\ Ngalal Mugo Damilil Imamah \\ Asalamu Ngalaik \\ Assalamu Ngalaik \\ Ngalal Musyaf Fangiil Qiyamah \\ Asalamu Ngalaik \\ Asalamu Ngalaik \\ Ngalal Mudhol Lalibil Chomamah \\ Asalamu Ngalaik \\ Asslamu Ngaliaik \\ Ngalal Mutaw Wajibil Karomah}

Menurut penuturan sesepuh kelompok Janengan "Margo Eling", lagulagu Janengan pada awalnya terdiri dari satu lagu pembuka, delapan belas lagu dan satu lagu penutup. Dengan demikian lagu Janengan awalnya hanya tediri dari 20 lagu. Namun demikian perkembangan kesenian populer seperti campursari dan lagu-lagu pop Sunda telah mempengaruhi lagu-lagu Janengan. Akibatnya dalam acara Janengan kini tidak hanya dilagukan lagulagu yang berjumlah dua puluh, tetapi juga lagu-lagu lain sesuai dengan pesanan masyarakat pendengar. Pengaruh kesenian populer ini bukan tanpa resiko karena ternyata juga menimbulkan kontroversi di kalangan internal pegiat seni Janengan. Sebagian peniat seni Janengan ingin tetap mempertahankan keaslian Janengan baik dari segi lagu maupun alat musik yang digunakan, sedangkan sebagian yang lain menghendaki diperlukannya pembaruan baik dari segi lagu maupun alat yang digunakan.

Dari naskah lagu Janengan bisa diketahui lagu syair-sayir Janengan merupakan bentuk integrasi nilai-nilai aqidah, syari'ah dan tasawuf yang dikemas secara estetis menggunakan metrum Jawa yang sudah di adaptasi. Hal ini terbukti dengan penggunaan istilah dalam metrum Jawa seperti macapat. Salah satu judul lagu Janengan misalkan adalah "Bowo" Dandanggula Sida Asih.

Dalam perkembangannya Janengan juga mengadopsi lagu-lagu Jawa mapun Sunda yang telah populer di masyarakat. Salah satu grup Janengan Dewi Masitoh misalkan disamping tetap mementaskan lagu-lagu Janengan asli, juga mementaskan lagu-lagu lain seperti Waru Doyong (lagu khas Cirebon) dan juga lagu Bojo Loro (lagu campursari Jawa). Meski lagu yang di- 
ambil adalah lagu-lagu Jawa populer, namun syairnya merupakan syair gubahan yang tetap berisi ajaran-ajaran Islam. Disamping itu lagu-lagu baru dalam Janengan juga diciptakan dalam penyadaran masyarakat akan pentingnya pembangunan di Kebumen. Hal ini bisa dilihat dari lagu Kebumen Beriman, Pantai Ayah dan Surak-Surak. Dari ketiga lagu tersebut bisa dipastikan seni tradisi Janengan telah bersinggungan dengan kepentingan pragmatis pembangunan di Kota Kebumen. Bahkan menurut ketua Janengan "Margo Eling", dalam setiap pementasan Janengan, lagu-lagu semacam itu selalu menjadi permintaan masyarakat.

Dengan berkembangnya lagu-lagu dalam Janengan maka berkembang pula fungsi Janengan bagi masyarakat Kebumen. Pada awalnya dengan modelnya yang sangat sederhana baik dari segi alat musik maupun lagu, Janengan lebih kental berfungsi sebagai sarana dakwah untuk mengembangkan nilai-nilai Islam. Belakangan memiliki fungsi-fungsi antara lain fungsi dakwah, fungsi edukatif, fungsi rekreatif (hiburan) dan fungsi pembangunan.

Secara rinci tema isi lagu-lagu Janengan awal bisa dijelaskan sebagai berikut:

\title{
a. Tema Akidah
}

Lagu-lagu Janengangan yang berisi akidah bisa dilihat pada bait-bait berikut:

\author{
Lailaha Illallah \\ Lailaha Illallah \\ Lailaha Illallah \\ Muhammadur Rasulullah \\ Allah-Allah-Allah Allah Tuhan Allah \\ Allah-Allah-Allah Rabuna \\ Allah-Allah-Allah Li Hasbuna \\ Allah-Allah-Allah Datullah \\ Allah-Allah-Allah Sifatullah \\ Allah-Allah-Allah Wujudullah
}

Dilhat dari komposisi dan diksi syair di atas sangat sedikit. Akan tetapi kandungannya merupakan inti dasar akidah Islam yang biasa dikenal dengan syahadat tauhid dan syahadat rasul. Syair itu juga mengungkapkan wujud Allah sebagai Tuhan yang memiliki dzat dan sifat yang menjadi muara kehidupan.

Walisongo, Volume 21, Nomor 2, November 2013 


\section{b. Tema Tasawuf}

Berbeda dengan syair dengan tema akidah, syair Janengan dengan tema tasawuf berisi ajakan untuk mengingat Allah. Simak syair Janengan "Gobyog Dikrullah" berikut:

E Dzikrullah Allah Allah Dzikrullah

Yen Dzikira Sira Maring Gusti Allah

E Sirrullah Allah-Allah Isirullah

E Yola Datullah, Allah Allah Allah Yola Datullah

ESifatullah, Allah Allah Wujudullah

EUlehana Kulo Dumateng Dunya

E Umahena Kula Niki Pinggireng Masjid

ESlahat Makmum Shalat Sunat Kulo Lampahi

Tema mengingat Allah juga terdapat dalam syair dengan judul "Yo Elingo"

E. Yo Eling Sira, Sira Eling Maring Pangeran

Yola Sira Pada Eling Fardu Sunnat Sira Lakonono

E Yo Elinga Umat Kanjeng Nabi

Kabeh Mumpung, Kabeh Mumpung Neng Naglam Dunya

Yola Pada Ngaji Sira Ginawe Sangu

Gawe Sangu Maring Suwarga

E Yo Elinga Sira Maring Pangeran

Sira Manungsa Mumpung Aneng Ngalam Dunya

Lamon Sira Sira Ora Eling

Sira Manungsa Aneng Kubur Dipun Siksa

Disamping itu juga terdapat tema-tema lain seperti tema tentang keadaan orang diakherat kelak. Namun demikian tema-tema yang terkait dengan akherat itu juga terintegrasi ke dalam syair-syait nasehat untuk berbuat kebaikan.

\section{Pemain}

Pada awalnya alat musik Janengan hanya terdiri dari alat-alat perkusi yang berjumlah tujuh buah. Oleh karena itu jumlah minimal pemain Janengan adalah tujuh orang. Di Kebumen sekarang ini jumlah orang yang terlibat dalam permainan musik antara lima belas sampai 20 orang yang biasanya 
tediri dari seorang dalang, tujuh orang penabuh alat musik dan sejumlah orang anggota sebagai penjawab syair.

\section{Keberlangsungan dan Problem Konservasi Janengan}

Sebagaimana telah diuraikan sebelumnya, meskipun Janengan merupakan musik yang telah berusia ratusan tahun, namun tetap bisa bertahan di tengah masyarakat yang terus mengalami perubahan. Bahkan lebih dari 400 grup Janengan eksis di tengah masyarakat Kebumen. Ada beberapa penjelasan yang bisa digunakan untuk menganalisis keberlangsungan seni Janengan. Bagi masyarakat Kebumen, Janeng merupakan kesenian daerah yang tergolong tradisional. Kesenian itu sejak sekian lama telah menjadi jantung kesenian tradisional di kabupaten tersebut. Sebagian tokoh seni Janengan menyatakan Janengan adalah identitas seni tradisi Islam Kebumen yang membedakannya dengan seni daerah lain seperti dolalak di Purworejo. "Janengan adalah warisan leluhur para wali yang berbeda dengan dolalak di Purworejo. Dari namanya saja dolalak kan berasal dari kata dolal yang artinta sesat. Sementara Janengan kan berisi salawat dan nasehat dan cara mainnya tidak seperti dolalak yang mengandalkan tarian perempuan".3

Memang keberadan Janengan kini berbeda dengan sebelum tahun 1980-an. Pada tahun-tahun itu sebelum dangdut, musik pop, campursari, dan kesenian modern lain populer, musik Janengan sering dimainkan di manamana: di balai desa, kecamatan, pendopo kabupaten, dan di tempat orang punya hajat. Janengan pada saat itu menjadi hiburan dan tontonan laris yang banyak digemari masyarakat Kebumen. Karena itu, pertunjukan rutin seni Janengan atau juga biasa disebut Jam Janeng yang diadakan di salah satu stasiun radio swasta setiap malam Jum'at setidaknya mempu membangkitkan rasa "kangen" masyarakat terhadap kesenian tersebut. Disamping itu festival Jam Janeng yang dilaksanakan oleh Pemerintah Kebumen juga menjadi terobosan strategis, setidaknya karena dua hal. Pertama, era globalisasi yang terus bergulir membawa kebudayaan transnasional (budaya asing) ke wilayah Indonesia. Budaya-budaya asing yang kemudian dikenal sebagai budaya modern itu secara perlahan menggerus budaya daerah. Nuansa

3 Wawancara dengan M. Nur Hidayat, 10 Juli 2010.

Walisongo, Volume 21, Nomor 2, November 2013 
kearifan lokal (local wisdom) semakin sirna dan tergantikan dengan gegap budaya modern tersebut. Budaya lokal sangat sulit mempertahankan eksistensinya. Jika ingin bertahan, membutuhkan kekuatan yang ekstra. Jika tidak mampu bertahan, bisa mengambil dua kemungkinan: akan hilang dan tergantikan dengan budaya moderan, atau memilih "perkawinan budaya" antara budaya lokal dan modern atau yang diistilahkan Roland Robertson sebagai glokalisasi. Dalam tataran itulah, posisi budaya lokal saat ini. Kedua, Kebumen sendiri menurut para pekerja seni dan budaya kini sesungguhnya sedang menggalang kekuatan ekstra untuk mempertahankan kebudayaan lokalnya. Oleh karena itu festival Janengan itu merupakan terobosan luar biasa dan merupakan strategi jitu untuk mempertahankan budaya lokal. Apalagi festival itu diadakan bagi anak-anak Sekolah Dasar. Anak-anak SD adalah potensi sekaligus fondasi bagi tegaknya budaya. Anak-anak yang masih dalam taraf belajar, memang sudah seharusnya sejak dini dikenalkan dengan budaya lokalnya. Hal itu agar budaya tersebut mampu merasuk, tidak hanya ke dalam otak mereka, namun juga ke dalam sanubarinya. Dampaknya, tentu saja ketika mereka dewasa. Mereka akan mampu mempertahankan kebudayaan lokal tersebut, karena telah menyatu dengan dirinya. Dengan upaya ini pula tampaknya keberlangsungan Jenangan akan terus berkembang seiring dengan perkembangan budaya pop.

Keberadaan seni tradisi Janengan di tengah masyarakat Muslim Kebumen juga tidak lepas dari pro dan kontra. Sebagian masyarakat berpandangan bahwa seni itu merupakan warisan para wali yang perlu di pelihara. Namun sebagian yang lain melihat kesenian semacam itu tidak ada dasarnya dalam al-Qur'an. Janengan menurut pendapat kedua ini hanya merupakan tradisi yang belum bisa dilepaskan oleh masyarakat pemiliknya. Pro dan kontra mengenai Janengan ini sekaligus merefleksikan ketegangan yang belum terselesaikan hingga kini mengenai hubungan antara Islam dan kebudayaan.

Di sisi lain sebagai seni tradisi Janengan belum sepenuhnya mendapat dukungan dari pemerintah terutama dalam kerangka pembangunan kebudayaan. Salah saru pegiat seni Janengan M. Nurhidayat mengungkapkan bahwa keterpinggiran kebudayaan dan seni tradisi yang katanya merupakan warisan leluhur yang harus dipelihara dan dilestarikan yang diungkapkan oleh pejabat pemerintah masih merupakan kalimat retorika yang selalu di- 
dengungkan kalangan pemerintah di acara-acara seremonial seni budaya. Demikian pula halnya dengan Undang-Undang Nomor 32 Tahun 2004 yang menggantikan Undang-Undang Nomor 22 Tahun 1999 tentang Pemerintahan Daerah.

Lahirnya UU tersebut yang menuntut perubahan sikap (attitude) pemerintah daerah (provinsi, kota, dan kabupaten) untuk lebih mengarah pada steering, assisting, fasilitator, koordinator, dan menjadi mitra, nyatanya kurang begitu terasakan. Pelaku seni budaya tradisi hingga kini masih harus memosisikan dirinya sebagai pewaris tunggal yang senantiasa harus menjaga keutuhannya. Karena memiliki wewenang untuk mengelola daerahnya, hampir semua daerah menjadikan sektor seni budaya sebagai program nomor kesekian dibandingkan dengan program lainnya. Di Kebumen, meskipun ada upaya untuk mencanangkan Kebumen sebagai kota budaya setara dengan Jogya maupun Solo, nyatanya sangat jarang bahkan terkadang tidak ada sama sekali kegiatan yang diselenggarakan pemerintah yang menandakan sebagai kota seni budaya.

Demikian pula halnya dengan Instruksi Presiden RI Nomor 16 Tahun 2005 tentang Kebijakan Pembangunan Kebudayaan dan Pariwisata di mana ditegaskan agar pemerintah daerah mengambil langkah nyata guna mengoptimalkan akselerasi pembangunan kebudayaan dan pariwisata dalam upaya tidak hanya melestarikan tetapi juga menyejahterakan masyarakat, membuka lapangan kerja, dan memeratakan pembangunan. Tapi dalam implementasi di lapangan tidak dirasakan seniman maupun budayawan.

Bahkan Peraturan Menteri Dalam Negeri Nomor 13 Tahun 2006 tentang Pengelolaan Keuangan Daerah secara tegas menyatakan bahwa Satuan Kerja Pemerintah Daerah (Dinas) tidak memberikan secara langsung bantuan. Pengeluaran bantuan dari bantuan khusus atau dana hibah hanya menjadi wewenang gubernur ataupun kepala daerah (wali kota dan bupati). Kondisi ini menjadikan budaya dan seni tradisi semakin terpuruk serta kurang terperhatikan karena setingkat dinas (kebudayaan dan pariwisata) tidak memiliki wewenang lagi memberikan bantuan kegiatan ataupun pemeliharaan kebudayaan dan seni tradisi.

Karena hambatan-hambatan itulah, demikian menurut M. Nurhidayat, meskipun usaha-usaha untuk meminta dukungan dari pemerintah telah beberapa kali dilakukan tetapi sampai hari belum pernah berhasil. 


\section{E. Kesimpulan}

Musik tradisional Islam-Jawa Janengan merupakan perwujudan dari perpaduan tiga unsur tradisi musik, yakni tradisi musik Jawa, dan tradisi musik Islam Timur Tengah (Arab) dan kini telah dikembangkan dengan kombinasi musik Barat seperti Pop. Perpaduan di antara ketiga unsur tradisi musik yang berbeda ini membentuk suatu hasil kreativitas yang unik.

Kesatupaduan di antara kedua unsur tradisi musik tersebut melahirkan nuansa musikal yang khas serta berbeda dengan kebanyakan nuansa musik islami pada umumnya. Namun demikian secara keseluruhan tampak kesan komposisi musik Janengan adalah nuansa musik Jawa. Dengan demikian, tepatlah apabila musik Janengan ini dinamakan "musik tradisional JawaIslam". Musik tradisional Islam-Jawa ini terbentuk dari perpaduan antara ketiga unsur tradisi musik-musik Barat, musik Jawa, dan musik Islam-ini juga melahirkan nilai-nilai tersendiri, meliputi: nilai-nilai musikal, nilai-nilai kultural, dan nilai-nilai religius.

Nilai-nilai musikal tampak pada lagu (vokal), iringan (instrumental), dan hubungan di antara lagu dan iringannya; nilai-nilai kultural (Jawa) tampak pada bahasa dan unsur-unsur musik Jawa yang di antaranya meliputi tangga nada dan gramatika/idiom-idiom musiknya; dan nilai-nilai religius tampak pada tema dan isi lirik lagu-lagunya yang bertemakan keagamaan Islam dan berisi hal-hal yang berkaitan dengan keimanan, perintah untuk menjalankan syariat Islam dan larangan untuk tidak berbuat dosa dan kesalahan agar umat manusia dapat hidup selamat dan bahagia di dunia dan di akhirat.

Seni tradisi Janengan ini menghadapi masalah berupa pandangan yang masih kontroversial mengenai hubungan antara Islam dan seni. Sebagai seni tradisi Janengan menghadapi masalah yang terkait dengan kebijakan pemerintah yang masih kurang berpihak terhadap pemberdayaan seni tradisi. Dengan kenyataan ini maka konservasi seni tradisi Janengan bisa dilakukan dengan dua hal: pertama, para pegiat seni Janengan hendaknya mengembangkan kemampuan untuk mengeksplorasi potensi Janengan sebagai identitas kesenian Kebumen. Kedua, diperlukan pemikiran kembali mengenai hubungan antara Islam dan seni dalam kerangka pengembangan seni tradisi Islam. Ketiga, pemerintah hendaknya melakukan fasilitasi konservasi seni Janengan baik berupa pembinaan, penyelenggaraan festival, maupun penerbitan regulasi yang mendukung keberdaan seni tradisional.[w] 


\section{BIBLIOGRAFI}

Faisal, Sanafiah, Penelitian Kualitatif, Dasar dan Aplikasi, Malang: Yayasan Asah Asuh Asih, 1990.

Akbar PS, Usman, Metodologi Penelitian Sosial, Jakarta: Bumi Aksara, 1998

Nawawi, Hadari, Metodologi Penelitian Bidang Sosial, Yogyakarta: Gajah Mada University Press, 1983.

Lincon dan Guba, Naturalistic Inquiry, Beverly: Sage Publication, t.th.

Muh. Syafrudin, dkk., Sinkritisme Budaya Jawa-Islam (Sejarah dan Peranan Seni Jemblung Katong Wecana dalam Penyebaran Agama Islam di Kabupaten Ponorogo), Ponorogo: Fakultas Tarbiyah UNMUH, 2003.

Ritzer \& Goodman, Teori Sosiologi Modern, Jakarta: Prenada Media, 2004.

\section{Internet:}

Ade, Yusnita, dkk., "Rudat Mutiara Budaya yang Tersembunyi", dalam http://elanjurnalistik.bslogspot.com/2008/06/rudat.htm/. diakses pada tanggal 2 Januari 2009. 
